NBSIR 73-295

\title{
Interim Report No. 7. Chemical \\ Resistance and Physical Durability Testing of Coating Materials
}

Nonmetallic Coatings for Concrete Reinforcing Bars

James R. Clifton

Hugh F. Beeghly

Robert G. Mathey

Center for Building Technology

Institute for Applied Technology

National Bureau of Standards

Washington, D. C. 20234

\section{August 1973}

Interim Report for Period

April - June 1973

\section{Prepared for}

Federal Highway Administration U.S. Department of Transportation Washington, D. C. 20590 
NBSIR 73-295

\section{INTERIM REPORT N0. 7. CHEMICAL \\ RESISTANCE AND PHYSICAL DURABILITY \\ TESTING OF COATING MATERIALS}

Nonmetallic Coatings for Concrete Reinforcing Bars

James R. Clifton

Hugh F. Beeghly

Robert G. Mathey

Center for Building Technology

Institute for Applied Technology

National Bureau of Standards

Washington, D. C. 20234

August 1973

Interim Report for Period

April - June 1973

Prepared for

Federal Highway Administration

U. S. Department of Transportation

Washington, D. C. 20590

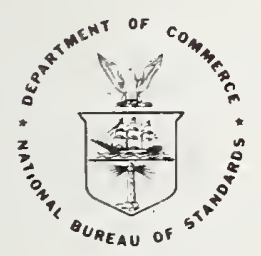

U. S. DEPARTMENT OF COMMERCE, Frederick B. Dent, Secretary

NATIONAL BUREAU OF STANDARDS, Richard W. Roberts, Director 



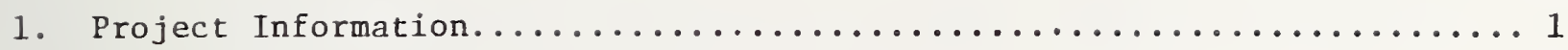

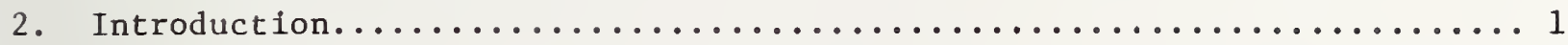

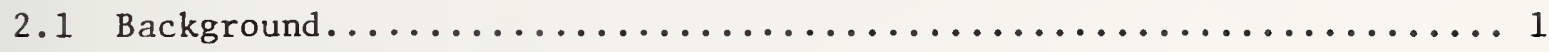

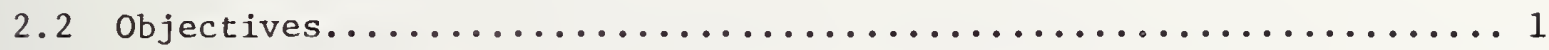

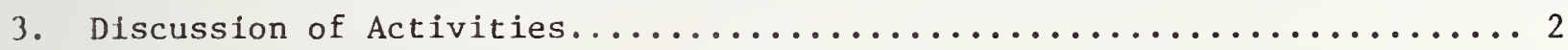

3.1 Chemical Resistance Testing.......................... 2

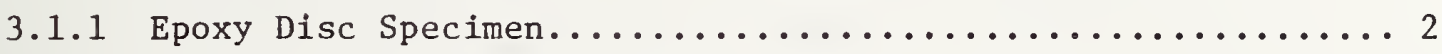

3.1.2 Coating on Reinforcing Bars....................... 3

3.2 Chloride Permeability............................. 4

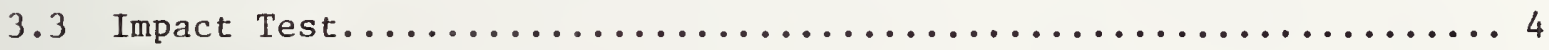

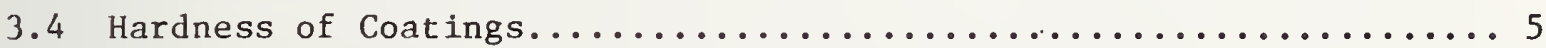

3.5 Corrosion Studies of Coated Reinforcing Bars Embedded in Concrete.. 6

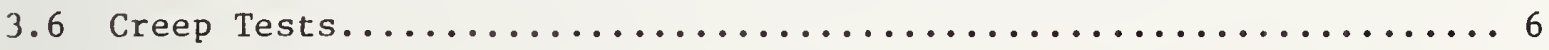

3.7 Qualification Specifications.......................... 7

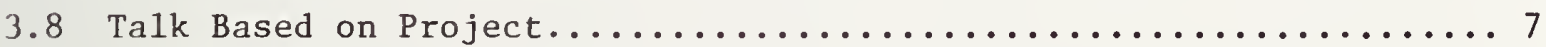

3.9 Pertinent Visits by NBS Staff........................ 8

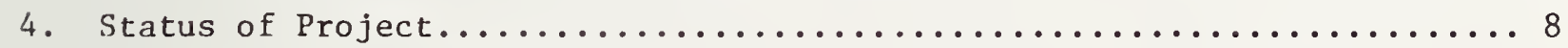

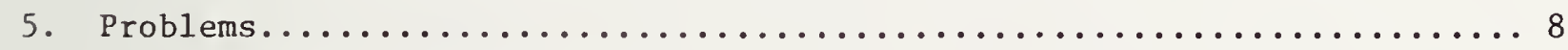

6. Work Planned for Next Quarter............................ 8

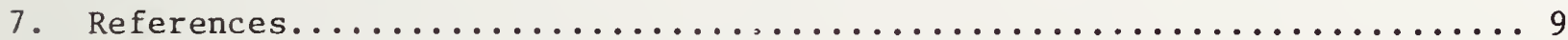



1. Project Information. Order No. 2-1-0614 Title: Nonmetallic

Coatings for Concrete Reinforcing Bars.

Date Project Initiated. 9-17-71

Research Agency. National Bureau of Standards

\section{Introduction}

2.1 Background. The early deterioration of the concrete of bridge decking, due to the corrosion of steel reinforcing bars, has become a major problem during the past decade. The annual cost of repairing bridge decks damaged in this manner is probably over 70 million dollars.

Normally, reinforcing steel is passive to corrosion when in an environment of the high basicity inherit in portland cement concrete. Chloride ions, however, are able to depassivate steel and thereby promote the active corrosion of steel.

Sodium chloride and calcium chloride are extensively used as de-icing agents on highways and bridges. When dissolved in water, these de-icing agents permeate through concrete decks to the regions where reinforcing bars are located. This leads to the corrosion of steel and subsequent cracking and spalling of the concrete. The amounts of sodium chloride and calcium chloride used as de-icing agents has increased substantially during the past decade.

2.2 Objectives. To investigate the protective qualities of organic coatings, especially epoxy systems, and to select the most promising materials for corrosion protection of concrete reinforcing bars, the 
selection to be based upon physiochemical testing with consideration given to the economics involved in coating and fabrication.

\section{Discussion of Activities}

The long-term chemical-resistance and chloride-permeability testing of coating materials has been completed and the final results are given in this report, along with the results of indentation-hardness and impact-resistance determinations of coating on reinforcing bars. The corrosion testing and structural-type testing (creep) is continuing, and will be mentioned.

Descriptions of the coating materials selected for evaluation in this work are 1 isted in table 1 . The methods of selecting and procuring the materials are discussed in NBS Report 10968 [1]. The techniques of preparing or obtaining test specimens (epoxy discs, coated rebars, thin epoxy films, etc.) were also described in NBS Report 10968 and will not be repeated in this current report.

Grade 60 , No. 6 steel reinforcing bars were used exclusively throughout this project.

\subsection{Chemical Resistance Testing}

3.1.1 Epoxy Disc Specimens. Disc shape castings of cured epoxy specimens (1iquids in their uncured states) were each immersed in the following: in water, in an aqueous solution of $3 \mathrm{M} \mathrm{CaCl}_{2}$; in an aqueous solution of $3 \mathrm{M} \mathrm{NaOH}$; and in a solution saturated with both $\mathrm{Ca}(\mathrm{OH})_{2}$ and $\mathrm{CaSO}_{4} \cdot 2 \mathrm{H}_{2} \mathrm{O}$ which also contained $0.5 \mathrm{M} \mathrm{CaCl}_{2} \cdot$ The specimens were immersed in water for a few minutes and wiped dry before measuring the original weights. Original weights of the discs varied from ca. 20 grams for solvent-containing systems to ca. 50 grams for the solventless epoxy 
systems. The temperatures of the test solutions were $24 \pm 1{ }^{\circ} \mathrm{C}$.

The specimens were immersed for over a year and the final immersion data are presented in table 2. In some cases two separate castings were made; indicated by two sets of data with different immersion times. In general, weights of the specimens changed by less than \pm 4 percent. The epoxies which in their uncured state contained solvents, generally lost weight and had greater weight changes than the solventless epoxies. In contrast to most specimens, Nos. 4, 9, and 16 gained weight in the $\mathrm{NaOH}$ and lost weight in the other solutions. An exception to the solvent containing epoxies is No. 7, which had the largest weight increase (13 to 19 percent) of all epoxies studied. The surfaces of both No. 7 and No. 9 specimens were converted from smooth to rough textures during the immersion period. No apparent deterioration was observed with the other epoxy specimens.

The weight losses of solvent-containing epoxies possibly may be associated with the gradual loss of retained solvents. Large weight increases may be indicative of porosity or swelling.

\subsubsection{Coating on Reinforcing Bars. The chemical resistances of} powdered epoxy systems were investigated by immersing coated reinforcing bars in aqueous solutions of $3 \mathrm{M} \mathrm{NaOH}$ and of saturated $\mathrm{Ca}(\mathrm{OH})_{2}$. The coatings were inspected for evidence of softening; color change, disbonding and changes in film integrity. The data are presented in table 3 for three polyvinyl chloride coatings, Nos. 23, 24, and 30; one pseudo-powder epoxy, No. 19 ; 10 powder epoxy coatings; and uncoated bars.

The rusting of some coated reinforcing bars and the uncoated bars in saturated $\mathrm{Ca}(\mathrm{OH})_{2}$ solutions is an interesting phenomenon, especially 
since the corrosion was only observed in the weaker alkaline solution, i.e. saturated $\mathrm{Ca}(\mathrm{OH})_{2}$ rather than $3 \mathrm{~N} \mathrm{NaOH}$. The $\mathrm{pH}$ of saturated $\mathrm{Ca}(\mathrm{OH})_{2}$, however, is near 13 which is sufficient to passivate steel. Therefore, the cause of the corrosion apparently lies in either the surface preparation or in the composition of the coatings. Note that the surfaces of the rusting specimens of numbers 38,39 and 40 were phosphatized before the epoxy was applied. Also, it was noted that the epoxy over the phosphated surfaces had softened during immersion. The surfaces of the companion non-rusting specimens were only sand blasted and the epoxy film had not softened. It is not obvious at this date why the same rusting phenomenon was not observed when the rebars with various surface preparations were immersed in the $3 \mathrm{M} \mathrm{NaOH}$.

3.2 Chloride Permeability. The chloride permeability characteristics of thin films ( $3-7$ mils) of cured epoxies have been measured by the methods described in NBS Report 10968 [1]. The final data are presented in table 4. Many of the epoxy films, Nos. 1, 17, 19, 31 and 39, appear to be essentially impervious to chloride ions. On1y two films, Nos. 13 and 16, permitted sufficient chloride ions to migrate through so that the corrosion threshold concentration of $0.2 \mathrm{M}$ [2] was reached.

\subsection{Impact Test}

The resistance of coatings on reinforcing bars to mechanical damage was assessed by the falling weight method. A test apparatus similar to that described in ASTM Designation G14-69T [3] was used along with a four pound tup. Impact occurred on the low-lying areas on the coated bars, i.e. areas between the deformations. The test was performed at $25^{\circ} \mathrm{C}$. 
The type and extent of damage to the coating caused by impact of 120 in-1b was visually assessed and the area of damage was measured. The data are listed in table 5. It has been concluded, arbitrarily, that the area of damage on a acceptable coating for rebars should not exceed 0.15 in $^{2}$ for a 120 in-1b impact.

\subsection{Hardnesses of Coatings}

The microhardness of coatings on steel reinforcing bars were measured by the indentation method, using an apparatus of the type described in ASTM Designation D1474-68 [4], and following the methods outlined therein. A 10 gram load was used.

The Knoop Hardness Number (KHN) was calculated with the equation:

$$
\mathrm{KHN}=\frac{\mathrm{L}}{\mathrm{AP}}=\frac{\mathrm{L}}{\ell^{2} \mathrm{Cp}}
$$

where $\mathrm{L}$ is the load applied to the indenter in kilograms; $\ell$ is the measured length of the long diagonal of the indentation in the coating in millimeters; $C_{p}$ is a constant with the value of $7.028 \times 10^{-2}$; Ap is the projected area of the indentation.

The results for five coatings on rebars are given in table 6 . No. 30 is a polyvinylchloride and has a relatively low hardness of $6.7 \mathrm{KHN}$, while the other four coatings are powder epoxies having hardnesses above $18 \mathrm{KHN}$. No. 22 and No. 31 are rebars coated with the same epoxy material but applied by different methods yielding different film thicknesses. The film thickness of No. 22 is ca. 25 mils (applied by the fluidized bed technique), while the film thickness of No. 31 is ca. 8 mils (applied using electrostatic spray gun). The microhardness was determined to be $20.7 \mathrm{KHN}$ for both coating films; therefore, it seems that the microhardness of the 
coating film alone was being measured and not the composite hardness of the coating and the steel substrate.

\subsection{Corrosion Studies of Coated Reinforcing Bars Embedded in Concrete}

The protective qualities of coating materials are also being evaluated by corrosion studies of coated rebars embedded in concrete specimens. These specimens have been partially immersed in an aqueous solution of 3.5 percent $\mathrm{NaCl}$. Any corrosion occurring is being monitored by taking both electrical potential and electrical resistance measurements. The fabrication of test specimens and the method of testing have been previously described [5].

The current data are presented in table 7. No evidence of cracks developing in the concrete cover nor of rust stain have been observed.

\subsection{Creep Tests}

The creep characteristics of coated steel reinforcing bars embedded with one end in concrete prisms and loaded under tension are being assessed and compared to the creep of uncoated reinforcing bars embedded and loaded in the same manner. The work in this reporting quarter involved loading the creep specimens and recording the initial measurements. The fabrication of test specimens and preparation of the test apparatus have been covered in a previous report [5].

Two levels of tensile stresses in the steel reinforcing bars, 15,000 and 30,000 psi, are being exerted by the compression of steel coil springs. The tensile stress in the rebar for each creep specimen is listed in table 8. Strain gages, with small intrinsic creep propertiés, and measurements of the changes in length of the compressed springs are being used for monitoring tensile loads in the rebars [5]. Both the 
free and loaded-end slip of the reinforcing bars embedded in the concrete prisms are being measured with dial gages.

The tests were just commenced at the end of this reporting quarter. Possibly, sufficient data will be available in the next reporting quarter to make tentative interpretations of the creep characteristics of coated and uncoated rebars.

\subsection{Qualification Specifications}

Qualification specifications that cover the requirements new coatings must meet for approval as acceptable coating for steel reinforcing of concrete bridge decks have been drafted by the NBS staff and forwarded to the FHWA.

\subsection{Talk Based on Project}

The following talk based on the project was given by Dr. James R. C1ifton:

"Organic Coatings for the Protection of Steel Reinforcement in Concrete Bridge Decking," staff meeting of the Center for Building Technology of NBS, April 19, 1973.

\subsection{Pertinent Visits by NBS Staff}

1. Dr. Clifton and Mr. Beeghly visited the Westinghouse Power Cooling Systems Department, Media, Pennsylvania, on Apri1 25, 1973, to discuss the use of epoxy coated reinforcing bars in the reinforced concrete of power plant cooling towers.

2. Mr. Beeghly visited H. C. Price Company, Fairless Hills, Pennsylvania on May 31, 1973, to witness the applications of a powder epoxy coating of duPont Company to rebars on a production-line basis. This production run was performed for the duPont Company and the Bethlehem Steel Company. 
3. Mr. Beeghly visited Taylor-Davis Company, Wilmington, Delaware, on June 5, 1973, to observe fabrication (bending, and cutting to size) of the bars coated by Price on May 31, 1973. The coating was only slightly damaged by the fabrication process.

\section{Status of Project}

A11 of the tests specified in the project-contract are either completed or are currently being performed.

\section{Problems}

It is the opinion of the NBS staff that both the creep and corrosion testings of reinforcing bars embedded in concrete should be continued until either the specimens fail or unequivocal test results are obtained. This will certainly necessitate continuance of these tests beyond the contract expiration date of September 30,1973 . It is recommended that these studies continue for at least one year beyond the contract expiration date.

\section{Work Planned for the Next Quarter}

The corrosion testing and creep testing of coated and uncoated reinforcing bars embedded in concrete will be continued.

Many of the drawings, photographs and tables to be included in the final report will be prepared.

Studies on the protective qualities of epoxy coatings on rebars will be completed and the results analyzed. 
1. J. Clifton, H. Beeghly and R. Mathey, "Interim Report No. 4, Screening Tests for Evaluating Materials." NBS Report 10968 (1973).

2. D. A. Hausman, "Steel Corrosion in Concrete," Materials Protection, 6, 19 (1967).

3. ASTM Designation 614-69T, Impact Resistance of Pipeline Coatings (Falling Weight Test).

4. ASTM Designation D 1474-68, Test for Indentation Hardness of Organic Coatings.

5. J. Clifton, H. Beeghly, E. Anderson and R. Mathey, "Interim Report No. 6, Corrosion and Creep Testing of Coated Reinforcing Bars in Concrete," NBS Interagency Report 73-229 (1973). 


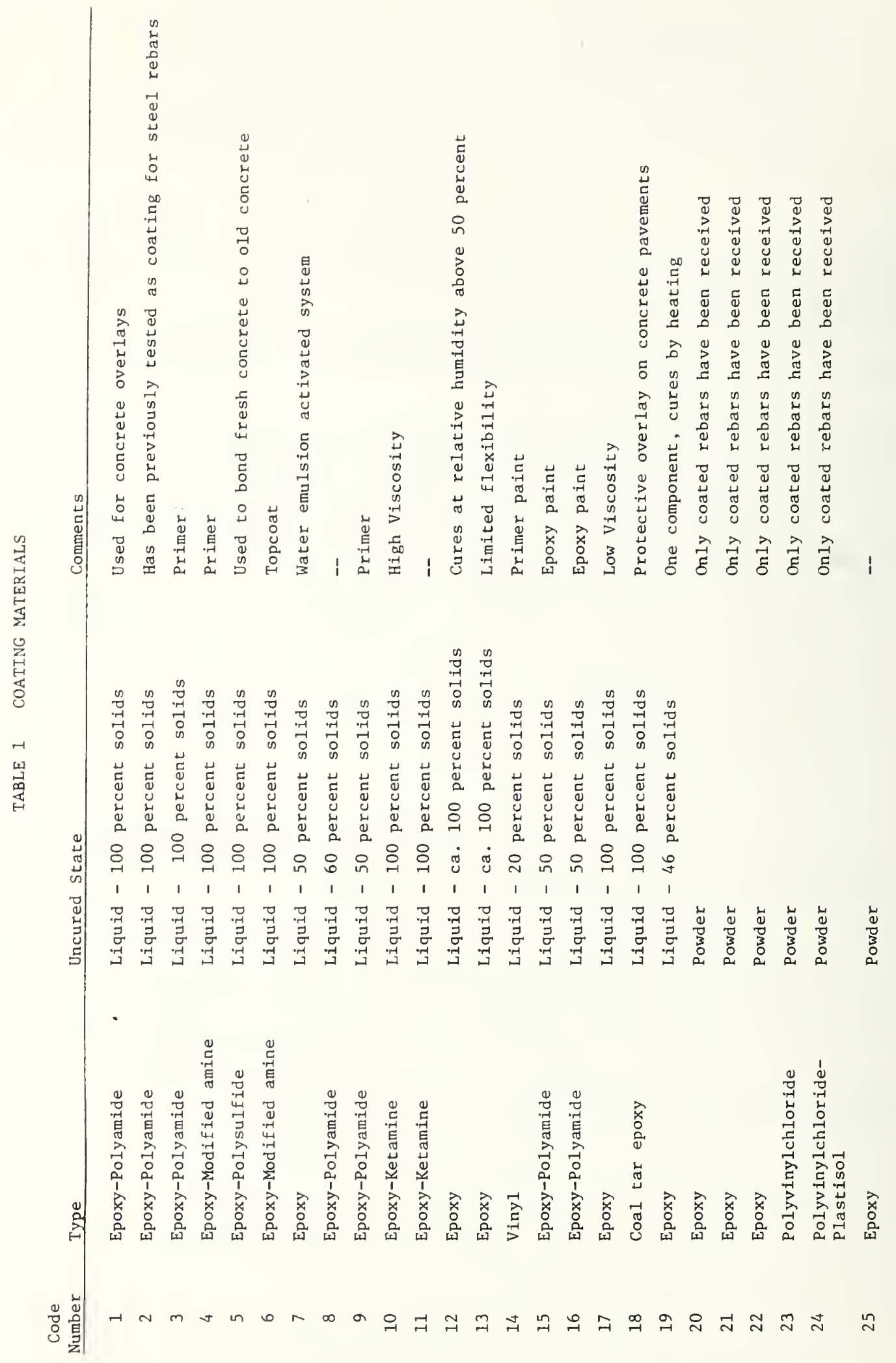




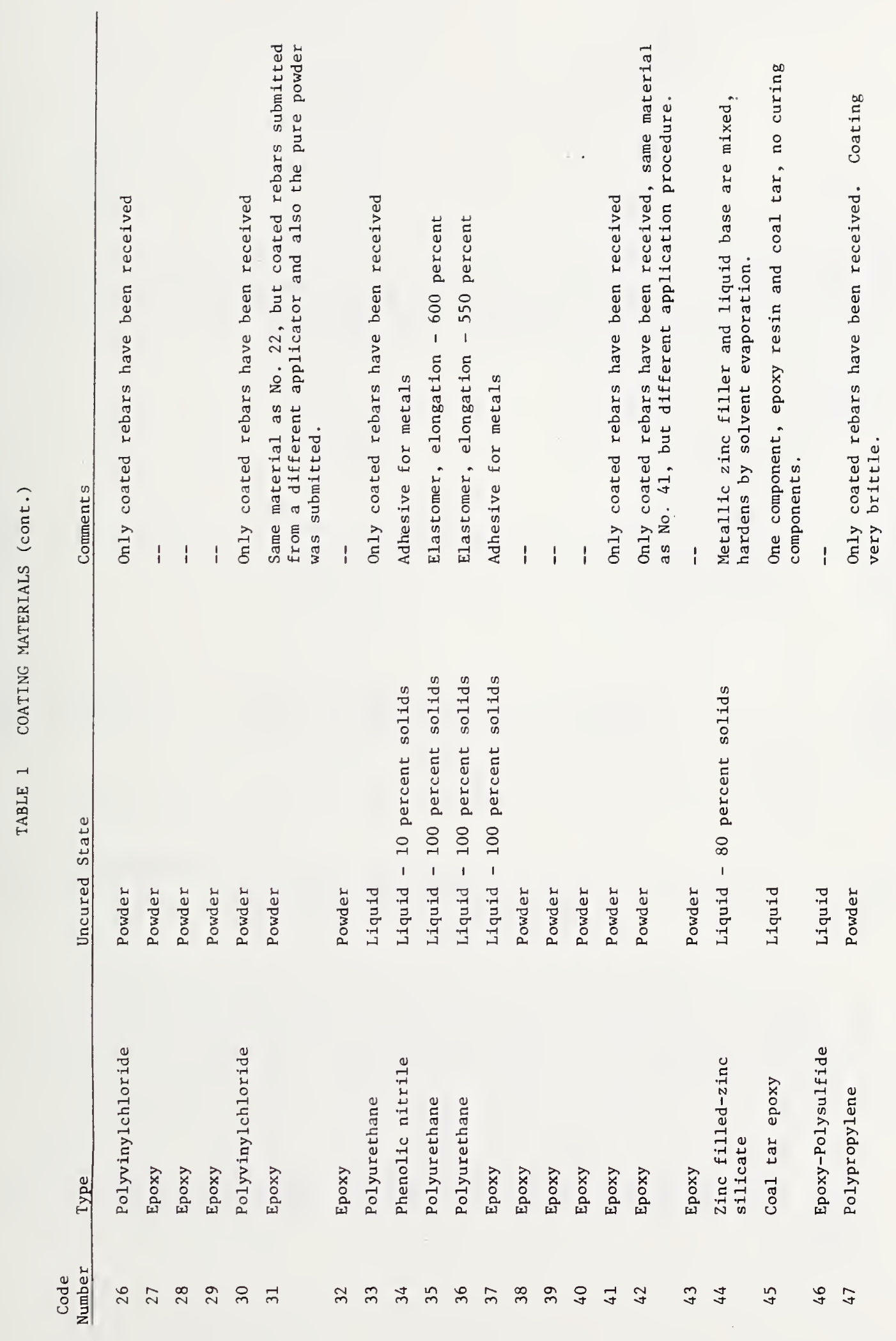




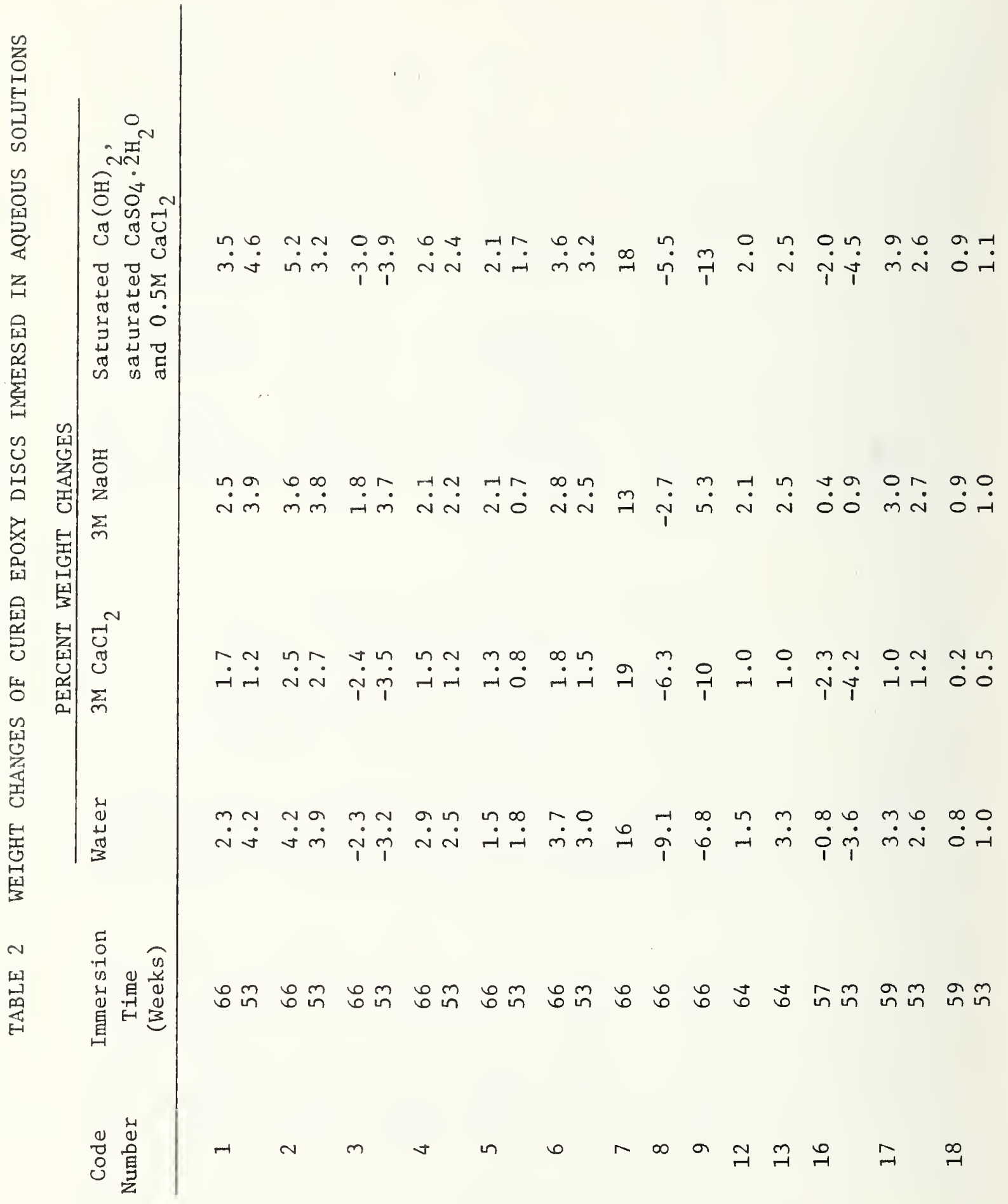


TABLE 3 IMMERSION TESTIHG OF COATINGS ON REINFORCING BARS 1 /

\begin{tabular}{|c|c|c|}
\hline $\begin{array}{c}\text { Code } \\
\text { Number }\end{array}$ & $3 \mathrm{~N} \mathrm{NaOH}^{2 /}$ & Saturated $\mathrm{Ca}(\mathrm{OH})^{2 /}$ \\
\hline 19 & No Change & $\begin{array}{l}\text { A. Very Badly Rusted } 3 / \\
\text { B. Bad1y Rusted } 3 /\end{array}$ \\
\hline 22 & No Change & No Change \\
\hline 23 & No Change & No Change \\
\hline 24 & No Change & No Change \\
\hline 25 & No Change & No Change $e^{6 /}$ \\
\hline 27 & No Change & No Change \\
\hline 28 & No Change & Slightly Rusted \\
\hline 29 & No Change & Slight1y Rusted \\
\hline 30 & No Change & No Change \\
\hline 31 & No Change & No Change \\
\hline 32 & No Change & No Change \\
\hline 38 & No Change & $\begin{array}{ll}\text { B. } & \text { Rusted } \frac{4 /}{4 /} \text { / } \\
\text { P. } & \text { Rusted } 1 /\end{array}$ \\
\hline 39 & No Change & $\begin{array}{l}\text { B. No Change } \frac{4 /}{5 /} \\
\text { P. Rusted } 4 \text { / }\end{array}$ \\
\hline 40 & No Change & $\begin{array}{l}\text { B. No Change } 4 / \\
\text { P. Rusted } 4 \text { / }\end{array}$ \\
\hline 41 & No Change & No Change \\
\hline $\begin{array}{l}\text { Uncoated } \\
\text { Rebar }\end{array}$ & No Change & Rusted \\
\hline
\end{tabular}

1/ No. 6 reinforcing coated by firms handing the respective coatings.

2/ Immersion time of 270 days.

3/ $A$ and $B$ are specimens from companion bars.

$4 /$ B denotes bars that were only sandblasted prior to application of the coating, while $\mathrm{P}$ indicates that their surfaces were also phosphatized prior to being coated.

5/ Rusting took place during the first 15 days of immersion; afterward rusting lifted most of epoxy from bar.

6/ No rust. Numerous smal1 blisters, apparently caused by penetration of water through coating, had been formed. 


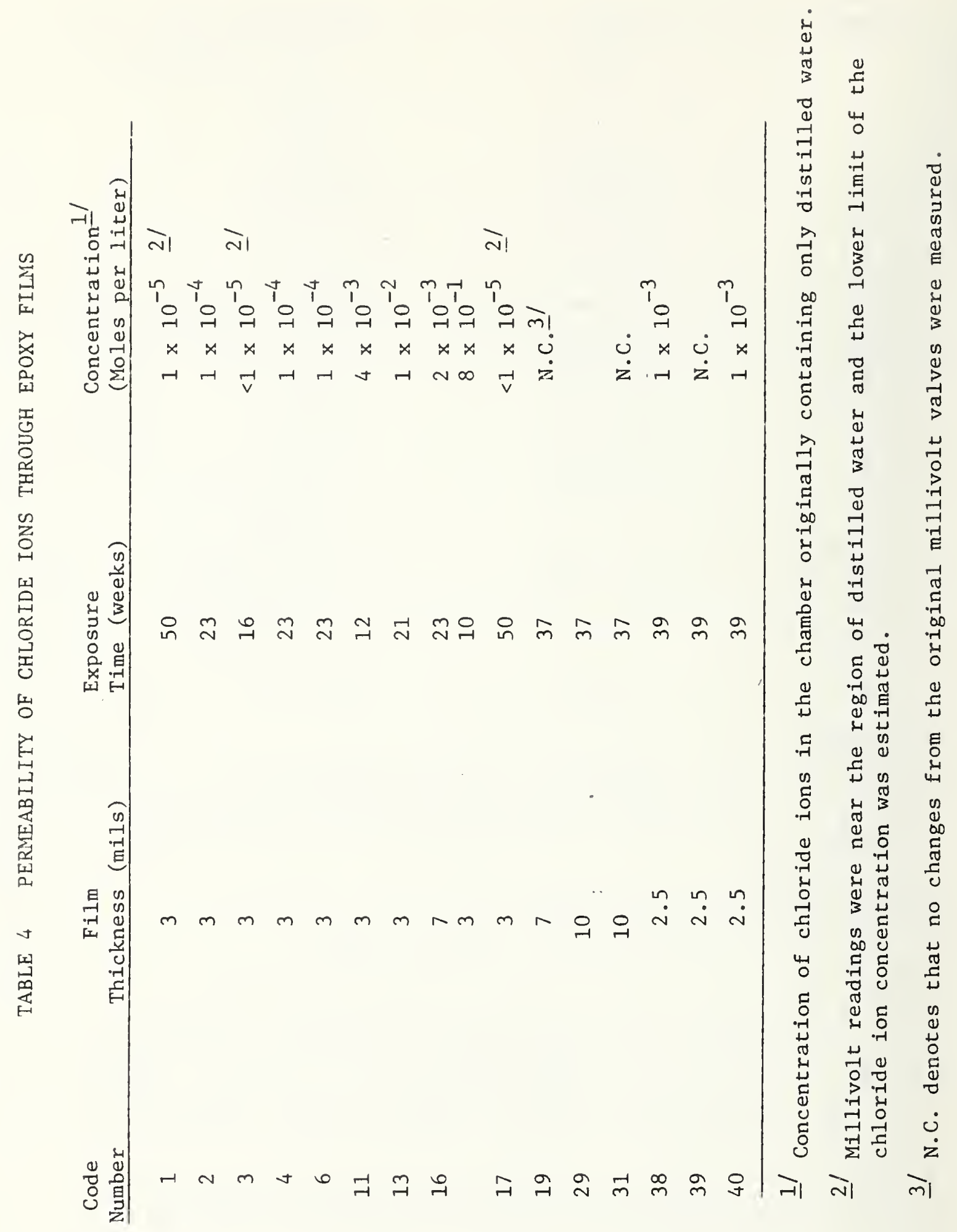




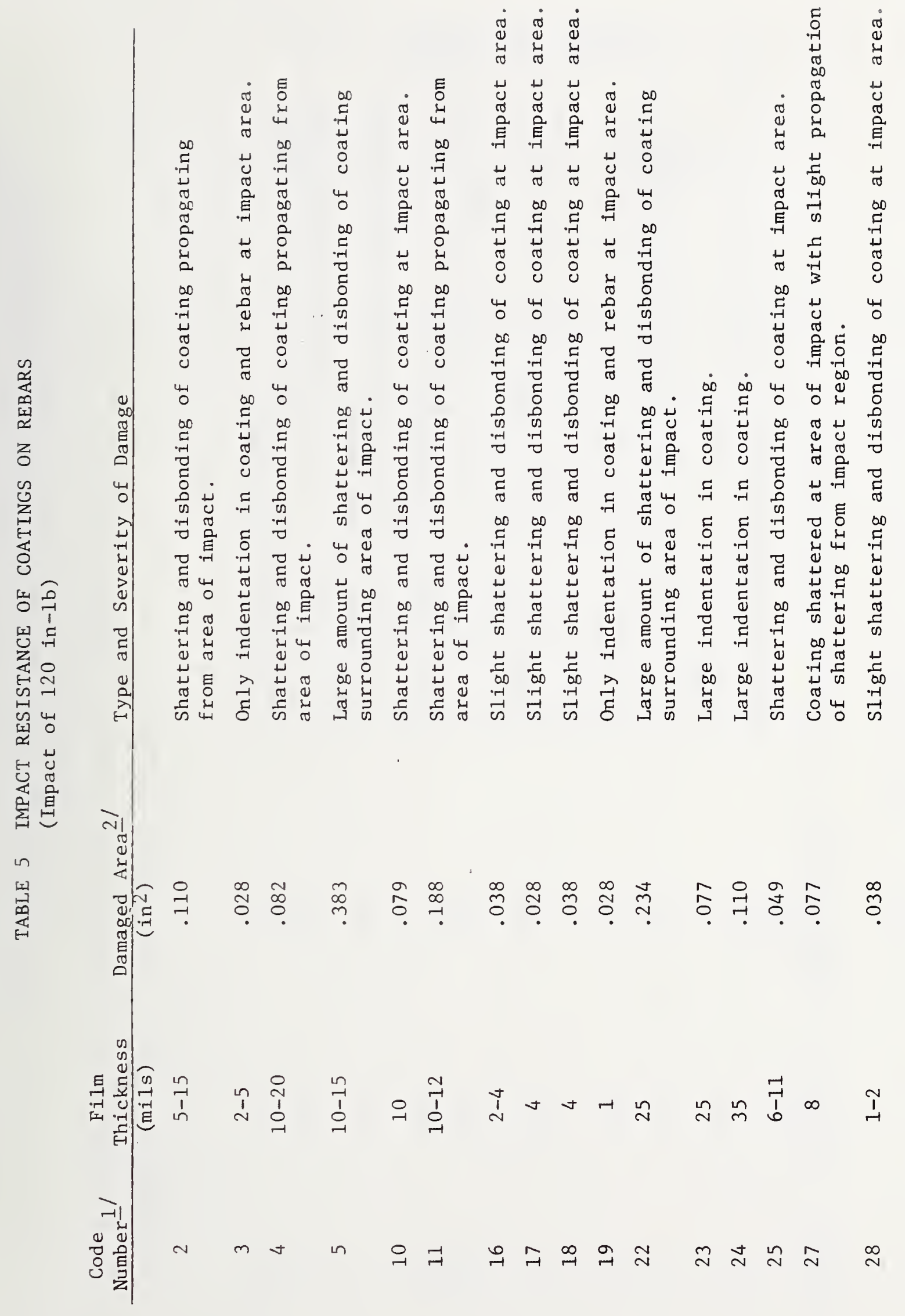




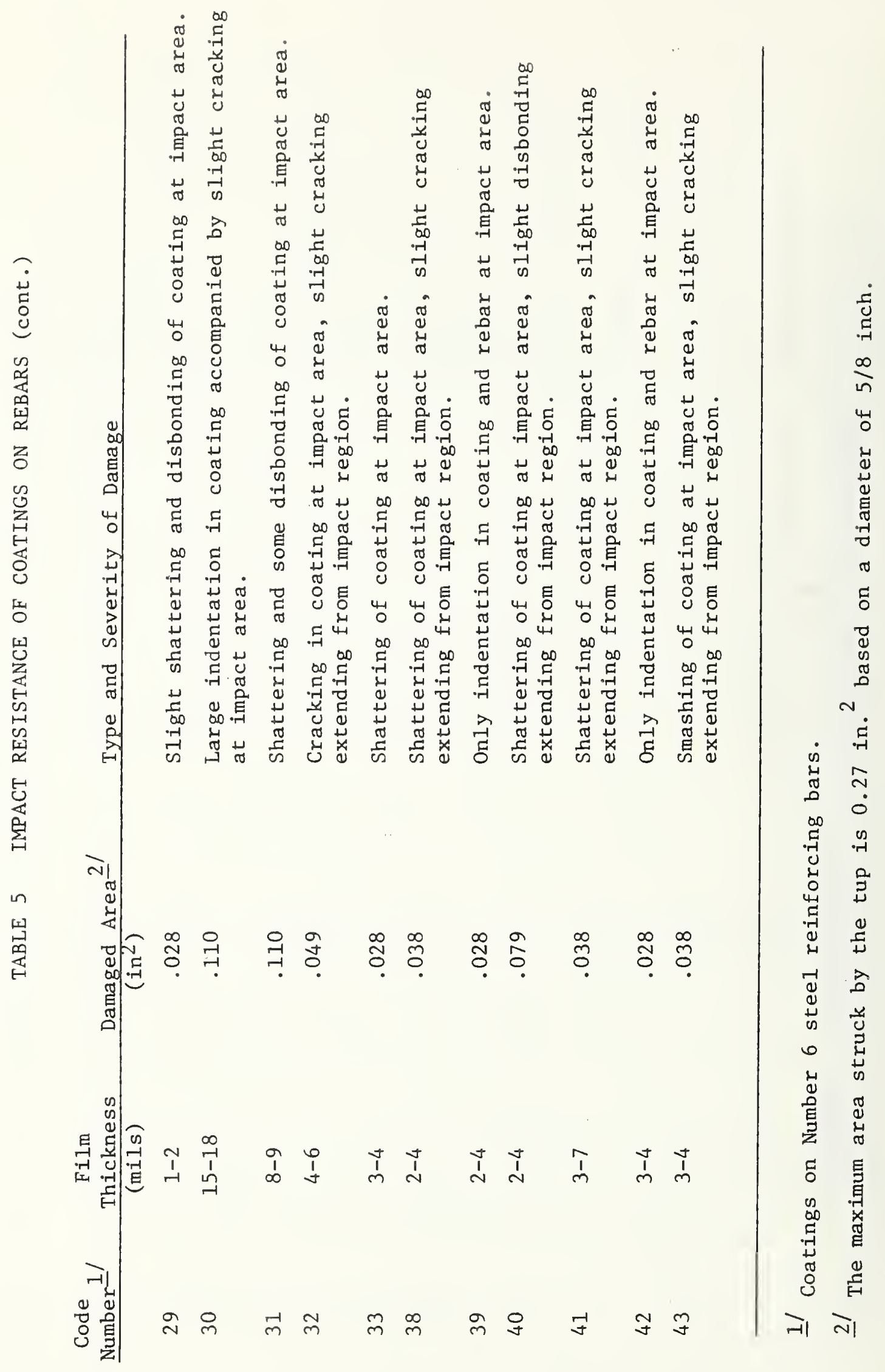


TABLE 6 INDENTATION HARDNESSES OF

COATINGS ON REINFORCING BARS

\begin{tabular}{cc}
$\begin{array}{c}\text { Code } \\
\text { Number }\end{array}$ & $\begin{array}{r}\text { Hardness } \\
\text { KHN 1 }\end{array}$ \\
\hline 22 & 20.7 \\
29 & 19.8 \\
30 & 6.7 \\
31 & 20.7 \\
39 & 21.2 \\
& \\
$1 /$ Knoop Hardness Number &
\end{tabular}


TABLE 7 ELECTRICAL POTENTIAL AND RESISTANCE MEASUREMENTS OF CORROSION-TEST SPECIMENS IN AQUEOUS SOLUTION OF 3.5 PERCENT NaC1.

Exposure Time (Hour)

\begin{tabular}{|c|c|c|c|c|c|c|}
\hline \multirow{2}{*}{\multicolumn{2}{|c|}{$\begin{array}{l}\text { Coating } \\
\text { Code No. } 1 /\end{array}$}} & \multicolumn{2}{|r|}{24} & \multicolumn{2}{|c|}{3480} & \multirow[b]{2}{*}{$\begin{array}{l}\text { Protective } \\
\quad \text { Rating } \\
\end{array}$} \\
\hline & & $\begin{array}{l}\text { EMF } \\
\text { (MV) }\end{array}$ & $\begin{array}{c}\text { Resistance } \\
\text { (ohms) }\end{array}$ & $\begin{array}{l}\text { EMF } \\
\text { (MV) }\end{array}$ & $\begin{array}{c}\begin{array}{c}\text { Resistance } \\
\text { (ohms) }\end{array} \\
\end{array}$ & \\
\hline 1 & $\begin{array}{l}\text { A } \\
\text { B }\end{array}$ & $\begin{array}{l}-345.0 \\
-408.8\end{array}$ & $\begin{array}{l}3.8 \times 10^{2} \\
7.0 \times 10^{2}\end{array}$ & $\begin{array}{l}-283.0 \\
-362.4\end{array}$ & $\begin{array}{l}3.9 \times 10^{2} \\
8.2 \times 10^{2}\end{array}$ & 3 \\
\hline $1-1$ & & -337.0 & $2.5 \times 10^{2}$ & -215.0 & $2.5 \times 10^{2}$ & - \\
\hline $1-\mathrm{S}$ & & -484.5 & $4.8 \times 10^{2}$ & -371.5 & $4.2 \times 10^{2}$ & - \\
\hline 3 & $\begin{array}{l}\text { A } \\
\text { B }\end{array}$ & $\begin{array}{l}-285.6 \\
-260.3\end{array}$ & $\begin{array}{l}3.1 \times 10^{2} \\
2.7 \times 10^{2}\end{array}$ & $\begin{array}{l}-432.4 \\
-365.5\end{array}$ & $\begin{array}{l}2.2 \times 10^{2} \\
2.4 \times 10^{2}\end{array}$ & 3 \\
\hline 4 & $\begin{array}{l}\mathrm{A} \\
\mathrm{B}\end{array}$ & $\begin{array}{l}-339.2 \\
-130.0\end{array}$ & $\begin{array}{l}2.4 \times 10^{4} \\
1.0 \times 10^{5}\end{array}$ & $\begin{array}{l}-142.3 \\
-115.5\end{array}$ & $\begin{array}{l}1.1 \times 10^{5} \\
1.4 \times 10^{4}\end{array}$ & 3 \\
\hline 18 & & -575.6 & $6.0 \times 10^{3}$ & $-003.0^{3 /}$ & $1.0 \times 10^{4}$ & 3 \\
\hline 19 & $\begin{array}{l}\text { A } \\
\text { B }\end{array}$ & $\begin{array}{l}-484.0 \\
-438.0\end{array}$ & $\begin{array}{l}5.6 \times 10^{2} \\
6.1 \times 10^{2}\end{array}$ & $\begin{array}{l}-399.5 \\
-282.0\end{array}$ & $\begin{array}{l}5.4 \times 10^{2} \\
6.0 \times 10^{2}\end{array}$ & 2 \\
\hline 25 & & -542.7 & $4.1 \times 10^{2}$ & $-271.4^{3}$ & $5.1 \times 10^{2}$ & 1 \\
\hline 27 & $\begin{array}{l}\mathrm{A} \\
\mathrm{B}\end{array}$ & $\begin{array}{l}-654.6 \\
-571.5\end{array}$ & $\begin{array}{l}1.3 \times 10^{4} \\
6.8 \times 10^{3}\end{array}$ & $\begin{array}{l}-167.0^{3 /} \\
-542.0\end{array}$ & $\begin{array}{l}7.2 \times 10^{4} \\
1.1 \times 10^{4}\end{array}$ & 3 \\
\hline 28 & & -461.5 & $5.2 \times 10^{2}$ & $-262.8^{3 /}$ & $5.4 \times 10^{2}$ & 3 \\
\hline 29 & $\begin{array}{l}\mathrm{A} \\
\mathrm{B}\end{array}$ & $\begin{array}{l}-376.3 \\
-403.4\end{array}$ & $\begin{array}{l}6.4 \times 10^{2} \\
6.6 \times 10^{2}\end{array}$ & $\begin{array}{l}-163.0^{3 /} \\
-360.5\end{array}$ & $\begin{array}{l}7.8 \times 10^{2} \\
5.4 \times 10^{2}\end{array}$ & 2 \\
\hline 30 & $\begin{array}{l}\mathrm{A} \\
\mathrm{B}\end{array}$ & $\begin{array}{l}-058.0 \\
-448.2\end{array}$ & $\begin{array}{l}1.0 \times 10^{5} \\
1.5 \times 10^{5}\end{array}$ & $\begin{array}{l}\text { N.C. } \\
-127.4 \text { / }\end{array}$ & $\begin{array}{l}2.1 \times 10^{5} \\
1.6 \times 10^{5}\end{array}$ & 1 \\
\hline 31 & $\begin{array}{l}\mathrm{A} \\
\mathrm{B}\end{array}$ & $\begin{array}{l}-359.8 \\
-092.2\end{array}$ & $\begin{array}{l}1.5 \times 10^{3} \\
9.8 \times 10^{3}\end{array}$ & $\begin{array}{l}-038.5^{3 /} \\
-013.5\end{array}$ & $\begin{array}{l}9.8 \times 10^{4} \\
6.2 \times 10^{4}\end{array}$ & 1 \\
\hline 38 & & -392.7 & $3.2 \times 10^{2}$ & -165.7 & $4.1 \times 10^{2}$ & 3 \\
\hline 39-Phos & $\begin{array}{l}\mathrm{A} \\
\mathrm{B}\end{array}$ & $\begin{array}{l}-513.0 \\
-536.2\end{array}$ & $\begin{array}{l}4.9 \times 10^{2} \\
5.0 \times 10^{2}\end{array}$ & $\begin{array}{l}-348.0 \\
-402.0\end{array}$ & $\begin{array}{l}4.7 \times 10^{2} \\
4.8 \times 10^{2}\end{array}$ & 3 \\
\hline $\begin{array}{l}\text { 40-Phos } \\
\text { 40-Phos }\end{array}$ & $\begin{array}{l}\mathrm{A} \\
\mathrm{B}\end{array}$ & $\begin{array}{l}-282.2 \\
-382.5\end{array}$ & $\begin{array}{l}2.5 \times 10^{2} \\
3.4 \times 10^{2}\end{array}$ & $\begin{array}{l}-256.6 \\
-325.5\end{array}$ & $\begin{array}{l}2.2 \times 10^{2} \\
2.7 \times 10^{2}\end{array}$ & 2 \\
\hline 40 & $\begin{array}{l}\mathrm{A} \\
\mathrm{B}\end{array}$ & $\begin{array}{l}-431.8 \\
-377.0\end{array}$ & $\begin{array}{l}2.9 \times 10^{2} \\
2.8 \times 10^{2}\end{array}$ & $\begin{array}{l}-398.0 \\
-316.9\end{array}$ & $\begin{array}{l}3.1 \times 10^{2} \\
2.3 \times 10^{2}\end{array}$ & 3 \\
\hline 41 & $\begin{array}{l}\mathrm{A} \\
\mathrm{B}\end{array}$ & $\begin{array}{l}-540.5 \\
-575.9\end{array}$ & $\begin{array}{l}6.0 \times 10^{3} \\
5.4 \times 10^{2}\end{array}$ & $\begin{array}{l}-432.2 \\
-324.4\end{array}$ & $\begin{array}{l}1.3 \times 10^{4} \\
2.5 \times 10^{4}\end{array}$ & 2 \\
\hline Uncoated & $\begin{array}{l}\mathrm{d} \\
\mathrm{A} \\
\mathrm{B}\end{array}$ & $\begin{array}{l}-334.2 \\
-264.0\end{array}$ & $\begin{array}{l}2.7 \times 10^{2} \\
2.6 \times 10^{2}\end{array}$ & $\begin{array}{l}-206.6 \\
-180.3\end{array}$ & $\begin{array}{l}2.3 \times 10^{2} \\
2.2 \times 10^{2}\end{array}$ & 4 \\
\hline
\end{tabular}

I/ $\mathrm{A}$ and $\mathrm{B}$ denote duplicate specimens.

2/ Ratings from Table 8 of reference [1].

3/ Large shifts in electrical potential attributed to sealing small holes in the silicone seal. 


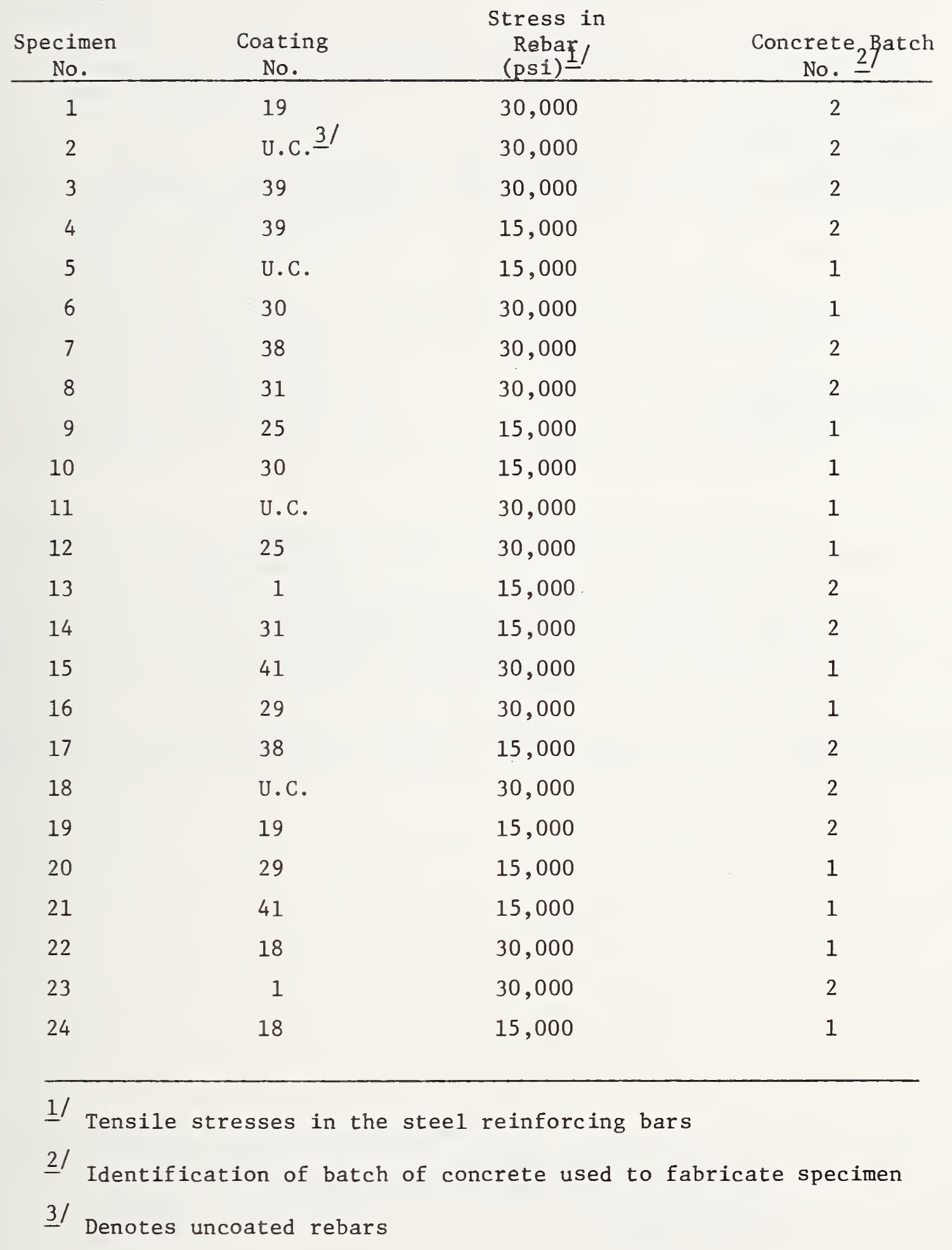



FORM NBS-114A $(1-71)$

U.S. DEPT. OF COMM.

BIBLIOGRAPHIC DATA

SHEET

1. PUBLICATION OR REPORT NO.
NBSIR $\quad 73-295$

2. Gov't Accession
No.

3. Recipient's Accession No.

5. Publication Date

Interim Report No. 7. Chemical Resistance and Physical

Durability Testing of Coating Materials. Nonmetallic Coatingo. Performing Organization Code

for Concrete Reinforcing Bars.

7. AUTHOR(S)

James R. Clifton, Hugh F. Beeghly, Robert G. Mathley

8. Performing Organization

y NBSIR 73-295

9. PERF ORMING ORGANIZATION NAME AND ADDRESS

NATIONAL BUREAU OF STANDARDS

DEP ARTMENT OF COMMERCE

WASHINGTON, D.C. 20234

12. Sponsoring Organization Name and Address

Federal Highway Administration

U. S. Department of Transportation

Washington, D. C. 20590

15. SUPPLEMENTARY NOTES

16. ABSTRACT (A 200-word or less factual summary of most significant information. If document includes a significant bibliography or literature survey, mention it here.)

The possibilities of Protecting steel reinforcing bars embedded in concrete of bridge decks from corrosion by using organic barrier-type coatings are being investigated in this project. This corrosion is accelerated by the chloride ions of the two most commonly applied deicing materials, sodium chloride and calcium chloride.

In this report, physiochemical studies performed on coatings and coated bars are discussed, including: immersion studies of coatings in corrosive solutions; impact and embedded in concrete.

17. KEY WORDS (Alphabetical order, separated by semicolons)

Bridge decks; corrosion; creep testing; epoxy coatings; polyvinylchloride coatings; steel reinforcing bars

\begin{tabular}{|c|c|c|}
\hline 18. AVAILABILITY STATEMENT & $\begin{array}{l}\text { 19. SECURITY CLASS } \\
\text { (THIS REPORT) } \\
\text { UNCL ASSIF IED }\end{array}$ & $\begin{array}{l}\text { 21. NO. OF PAGES } \\
19\end{array}$ \\
\hline $\begin{array}{l}\square \text { FOR OFFICIAL DISTRIBUTION. DO NOT RELEASE } \\
\text { TO NTIS. }\end{array}$ & $\begin{array}{l}\text { 20. SECUR ITY CLASS } \\
\text { (THIS PAGE) } \\
\text { UNCLASSIFIED }\end{array}$ & 22. Price \\
\hline
\end{tabular}



